\title{
Kajian Layanan Arsip Statis Bagi Pengguna Difabel : Studi Kasus Dinas Kearsipan dan Perpustakaan Daerah X
}

\author{
Yulia Nur Adiningsih \\ Pusat Air Tanah dan Geologi Tata Lingkungan
}

\begin{abstract}
This paper aims to describe the activities of static archive services for disabled users in the Archives Service and Regional Library X. The study focuses on the procedure of static archive services, and the realization of the availability and accessibility of services. The collection methods used in this study, namely literature review, participatory observation, and interviews. Literature review is done by taking notes from various references such as books, journals, final project, thesis, and regulations. Interviews were conducted with resource persons consisting of several levels of leaders and also users with disabilities. Participatory observation was also carried out directly by the writer in the static archive service room of the Archives Service and Regional Library $X$ for a period of two months. There are several factors that influence the success of static archive service activities for disabled users, including the policy factors, facility factors, and service personnel factors. For physical accessibility and non-physical accessibility, archival services at the Archive Service and Regional Library $X$ as a whole are good. But the service also needs to be equipped with several special facilities that are not yet available for disabled users, especially the deaf, visually impaired, and physically impaired.
\end{abstract}

Submitted: $14 / 11 / 2019$

Received: 22/01/2020

*Correspondence: Yulia Nur Adiningsih

yulia.nur.adiningsih@ mail.ugm.ac.id

KEYWORDS:

services;

archives;

user;

difabel

KATA KUNCI:

layanan;

arsip;

pengguna;

difabel

Daerah X Kengguna difabel di Dinas Kearsipan dan Perpustakaan perwujudan atas ketersediaan serta aksesibilitas layanan. Metode pengumpulan yang digunakan dalam penelitian ini, yaitu kajian pustaka, observasi partisipatif, dan wawancara. Kajian pustaka dilakukan dengan dengan cara membuat catatan dari berbagai referensi seperti buku, jurnal, tugas akhir, skripsi, dan peraturan. Wawancara dilakukan dengan narasumber yang terdiri atas beberapa tingkat pimpinan dan juga pengguna difabel. Observasi partisipatif juga dilaksanakan secara langsung oleh penulis di ruang layanan arsip statis Dinas Kearsipan dan Perpustakaan Daerah X selama kurun waktu dua bulan. Ada beberapa faktor yang mempengaruhi keberhasilan kegiatan layanan arsip statis bagi pengguna difabel, diantaranya yaitu faktor kebijakan, faktor fasilitas, dan faktor petugas layanan. Untuk aksesibilitas fisik dan aksesibilitas non fisik layanan arsip di Dinas Kearsipan dan Perpustakaan Daerah $X$ secara keseluruhan sudah baik. Namun dinas juga perlu dilengkapi beberapa fasilitas khusus yang belum tersedia bagi pengguna difabel, khususnya tunarungu, tunanetra, dan tunadaksa. 


\section{PENDAHULUAN}

Arsip merupakan warisan nasional lintas generasi yang perlu dipelihara dan dilestarikan. Arsip dapat menjadi sumber informasi dan komunikasi, sumber sejarah bangsa yang terjaga kelestariannya, dan juga sebagai sumber pertanggungjawaban nasional. Arsip, berdasarkan fungsinya diklasifikasikan menjadi arsip dinamis dan arsip statis. Arsip dinamis yaitu arsip yang digunakan secara langsung dalam kegiatan pencipta arsip dan disimpan selama jangka waktu tertentu (Arsip Nasional RI, 2009, 4). Arsip statis adalah arsip dari setiap lembaga publik atau swasta yang diputuskan layak dilestarikan secara permanen untuk tujuan referensi dan penelitian, dan telah disimpan atau dipilih untuk disimpan di lembaga kearsipan (Schellenberg, 2003, 16). Lembaga kearsipan adalah lembaga yang memiliki fungsi, tugas, dan tanggung jawab di bidang pengelolaan arsip statis dan pembinaan bidang kearsipan (Arsip Nasional RI, 2009, 5). Lembaga kearsipan di Indonesia terdiri dari lembaga kearsipan di tingkat pusat (Arsip Nasional Republik Indonesia), lembaga kearsipan di tingkat provinsi, lembaga kearsipan di tingkat kabupaten/ kota, dan lembaga kearsipan di lingkungan perguruan tinggi. Makalah ini akan berfokus pada lembaga kearsipan di tingkat daerah di salah satu provinsi di Indonesia.

Pembentukan Dinas Kearsipan dan Perpustakaan Daerah X didasarkan pada Peraturan Daerah Provinsi X nomor 9 tahun 2016 tentang pembentukan susunan perangkat Daerah Provinsi X. Dinas tersebut berupaya untuk bisa merekatkan simpulsimpul budaya yang beraneka ragam. Hal ini dilakukan dengan melestarikan khazanah arsip, seperti tersedianya arsip kolonial karesidenan X 1816, arsip pemerintahan X, arsip Puro X, arsip lembaga sosial masyarakat, arsip perusahaan swasta, arsip perorangan tokoh-tokoh $\mathrm{X}$, dan arsip pendidikan.

Khazanah arsip yang beragam dengan berbagai bentuk dan format ini tentunya bermanfaat bagi publik, khususnya bagi akademisi dan peneliti. Hal tersebut diwujudkan Dinas Kearsipan dan Perpustakaan Daerah X melalui upaya pelayanan arsip statis. Pelayanan arsip statis merupakan salah satu bentuk pelayanan publik dalam konteks sistem kearsipan nasional. Berdasarkan Undang-Undang Republik Indonesia Nomor 25 Tahun 2009 Tentang Pelayanan Publik, pada pasal 1 disebutkan bahwa pelayanan publik adalah kegiatan atau rangkaian kegiatan dalam rangka pemenuhan kebutuhan pelayanan sesuai dengan peraturan perundang undangan bagi setiap warga negara dan penduduk atas barang, jasa, dan/atau pelayanan administratif yang disediakan oleh penyelenggara pelayanan publik.

Setiap pengguna tentunya memiliki hak yang sama untuk dapat memperoleh aksesibilitas layanan arsip statis yang terdapat di Dinas Kearsipan dan Perpustakaan Daerah X, tak terkecuali pengguna penyandang disabilitas. Sebagaimana tercantum dalam Undang-Undang Republik Indonesia nomor 39 tahun 1999 Tentang Hak Asasi Manusia, dijelaskan pada pasal 14 ayat 1 dan 2 bahwa setiap orang berhak untuk berkomunikasi dan memperoleh informasi yang diperlukan untuk mengembangkan pribadi dan lingkungan sosialnya dan setiap orang berhak untuk mencari, memperoleh, memiliki, menyimpan, mengolah, dan menyampaikan informasi dengan menggunakan segala jenis sarana yang tersedia.

Begitu juga yang tercantum dalam Undang-Undang Nomor 19 Tahun 2011 Tentang "The Convention on the Human Rights of Persons with Disabilitie"(Hak-hak Penyandang Disabilitas) yang tertuang dalam resolusi PBB Nomor 60/106. Pada pasal 
9 ayat 1 tentang aksesibilitas, dinyatakan bahwa dalam rangka memampukan penyandang disabilitas untuk hidup secara mandiri dan berpartisipasi penuh dalam segala aspek kehidupan, maka negara-negara pihak harus melakukan langkah-langkah yang diperlukan untuk menjamin akses penyandang disabilitas terhadap lingkungan fisik, transportasi, informasi dan komunikasi, serta fasilitas dan pelayanan lainnya yang terbuka atau disediakan bagi publik, baik di perkotaan maupun di pedesaan atas dasar kesetaraan.

Berdasarkan latar belakang tersebut, maka penulis mengajukan pertanyaan penelitian sebagai berikut :

1. Bagaimana prosedur layanan arsip statis di Dinas Kearsipan dan Perpustakaan Daerah X?

2. Bagaimana upaya Dinas Kearsipan dan Perpustakaan Daerah X dalam memenuhi kebutuhan pengguna difabel dengan berbagai fasilitas dan aksesibilitas layanan yang mendukung, baik yang pernah dijalankan, yang sedang dijalankan, maupun yang akan dijalankan?

\section{METODE PENELITIAN}

Makalah ini merupakan hasil penelitian kualitatif deskriptif, yaitu mendeskripsikan prosedur layanan arsip statis bagi pengguna difabel di Dinas Kearsipan dan Perpustakaan Daerah X. Selain itu, penulis juga mendeskripsikan upaya yang dilakukan Dinas Kearsipan dan Perpustakaan Daerah X dalam rangka memenuhi kebutuhan pengguna difabel pada layanan arsip statis. Pengumpulan data dilakukan melalui teknik kajian pustaka, observasi partisipatif, dan wawancara terstruktur. Metode pengumpulan data dengan cara kajian pustaka dilakukan dengan dengan cara mengkaji dan membuat catatan dari berbagai referensi yang berhubungan dengan akses dan layanan arsip statis. Sumber pustaka yang digunakan pada penelitian ini terdiri dari buku, jurnal, laporan akhir studi, kebijakan, dan sumber referensi lain yang mendukung penulisan. Untuk memperkuat dan melengkapi data, penulis melakukan wawancara dengan dua bidang yang saling berhubungan dalam proses penyediaan akses arsip statis kepada publik, yaitu bidang Layanan dan Pemanfaatan arsip dan bidang Pengelolaan dan Pelestarian Arsip. Narasumber terdiri atas tiga tingkatan pimpinan yang dibagi berdasarkan tingkat jabatan di Dinas Kearsipan dan Perpustakaan Daerah X. Selain itu, penulis juga mewawancarai pengguna difabel (tunarungu dan tunawicara) yang pernah mengakses di Ruang Layanan Dinas Kearsipan dan Perpustakaan Daerah X. Observasi partisipatif dilaksanakan secara langsung oleh penulis di Dinas Kearsipan dan Perpustakaan Daerah X selama dua bulan. Adapun hal yang diamati yaitu segala sesuatu yang berkaitan dengan aksesibiltas fisik dan non-fisik dari layanan arsip statis di Dinas Kearsipan dan Perpustakaan Daerah X, maupun kegiatan-kegiatan kearsipan lain yang sedang berjalan di dinas tersebut.

\section{HASIL DAN PEMBAHASAN}

Arsip statis merupakan arsip yang memiliki nilai guna sekuner. Nilai guna sekunder adalah nilai kegunaan arsip di luar kepentingan organisasi (manajemen), terdiri dari nilai kebuktian (evidential values) dan nilai informasional (informational values) (Martono, 1994, 48). Oleh karena itu, arsip statis wajib dikelola dan dilestarikan. Pengelolaan arsip statis adalah proses pengendalian arsip statis secara efisien, efektif, dan sistematis. Proses ini meliputi akuisisi, pengolahan, preservasi, pemanfaatan, pendayagunaan, dan pelayanan publik dalam suatu sistem kearsipan 
nasional (Arsip Nasional RI, 2009, 7). Pengelolaan arsip statis di Dinas Kearsipan dan Perpustakaan Daerah X pun meliputi kegiatan akuisisi arsip statis, pengolahan arsip statis, preservasi arsip statis, serta akses arsip statis. Hal ini sesuai dengan Peraturan Daerah Provinsi X Nomor 1 Tahun 2015 tentang Penyelenggaraan Kearsipan di Provinsi X.

\section{Tahapan Pengelolaan Arsip Statis di Dinas Kearsipan dan Perpustakaan Daerah X}

Tahapan pertama dalam pengelolaan arsip statis adalah akuisisi arsip. Akuisi arsip statis merupakan proses penambahan khazanah arsip statis pada lembaga kearsipan yang dilaksanakan melalui kegiatan penyerahan arsip statis dan hak pengelolaannya dari pencipta arsip kepada lembaga kearsipan (Arsip Nasional RI, 2009 , 4). Unit kerja yang bertanggung jawab melaksanakan akuisisi arsip di Dinas Kearsipan dan Perpustakaan Daerah X adalah Seksi Akuisisi Arsip, Bidang Pengelolaan dan Pelestarian Arsip. Prosedur akuisisi arsip yang dilakukan institusi tersebut secara sederhana dapat dicermati pada gambar berikut:

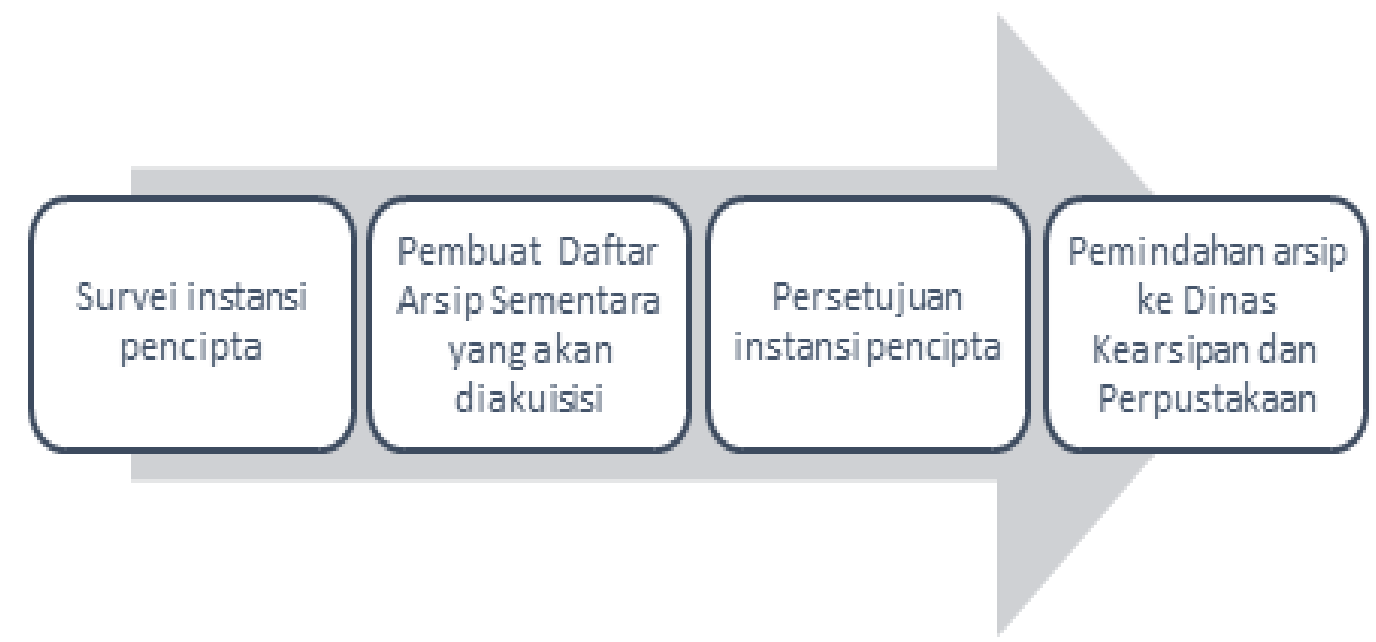

Gambar 1. Alur Akuisisi Arsip Statis di Dinas Kearsipan dan Perpustakaan Daerah X

Arsip statis diakuisisi berdasarkan rencana program kerja tahunan yang disusun oleh Seksi Akuisisi, Bidang Pengelolaan dan Pelestarian Arsip. Arsip yang berhasil diakuisisi di Dinas Kearsipan dan Perpustakaan Daerah X terdiri dari arsip tekstual dan arsip non tekstual.

Setelah diakuisisi, tahapan berikutnya adalah pengolahan arsip statis. Pengolahan arsip statis merupakan proses pembuatan sarana bantu penemuan kembali arsip berdasarkan kaidah kearsipan yang berlaku (Arsip Nasional RI, 2009, 4). Tanggung jawab pengolahan arsip statis di Dinas Kearsipan dan Perpustakaan Daerah X berada di bawah Seksi Pengolahan, Bidang Pengelolaan dan Pelestarian Arsip. Untuk penyimpanan setelah pengolahan berada di bawah tanggung jawab Seksi Pelestarian, Bidang Pengelolaan dan Pelestarian Arsip. Arsip statis diolah berdasarkan prinsip asal usul dan aturan asli. Pengolahan arsip statis dilakukan dengan mengolah informasi yang terekam dalam arsip menggunakan kartu deskripsi, kemudian diinput kedalam komputer. Tahap selanjutnya adalah penataan fisik arsip yang disesuaikan dengan daftar arsip yang telah diinput dari kegiatan pendeskripsian. Tahap akhir kegiatan pengolahan adalah penyimpanan fisik arsip di depo arsip statis.

Hasil akhir dari pengolahan adalah tersusunnya sarana temu kembali arsip berupa daftar arsip statis dan inventarisasi arsip (Wawancara dengan narasumber X 
pada 28 Februari 2019). Sarana temu kembali tersebut diserahkan kepada Bidang Layanan dan Pemanfaatan Arsip untuk disimpan di ruang baca layanan, dan juga di Ruang Depo Arsip Statis. Kegiatan yang dilakukan oleh seksi Pengolahan pada Bidang Pengelolaan dan Pelestarian Arsip (PPA) didominasi oleh pengolahan arsip tekstual.

Tahapan selanjutnya adalah preservasi arsip statis. Preservasi arsip statis merupakan kegiatan pemeliharaan, perawatan, serta penjagaan arsip terhadap berbagai unsur perusak arsip (Arsip Nasional RI, 2019, 5). Kegiatan preservasi terdiri dari preservasi preventif dan preservasi kuratif. Preservasi preventif merupakan tindakan pencegahan sbelum terjadinya kerusakan pada arsip, sedangkan preservasi kuratif atau yang biasa disebut dengan restorasi/perbaikan arsip.

Penanggung jawab kegiatan pelestarian arsip statis di Dinas Kearsipan dan Perpustakaan Daerah X adalah Seksi Pelestarian, Bidang Pengelolaan dan Pelestarian Arsip. Untuk pelestarian arsip tekstual, kegiatan preservasi preventif yang dilakukan dinas yaitu alih media, pengendalian hama terpadu, dan perawatan penyimpanan arsip tekstual. Adapun kegiatan preservasi kuratif yang dilakukan terdiri dari laminasi dan enskapsulasi arsip tekstual.

Untuk arsip non tekstual, yaitu berupa arsip audio visual, kegiatan perawatannya dilakukan sesuai dengan prioritas perawatan, misalnya terhadap fisik arsip yang rusak dan berjamur (Wawancara dengan narasumber Y pada 6 Maret 2019). Arsip yang terkena jamur dibersihkan dengan menggunakan alkohol. Jika pada arsip rekaman suara atau video, pita terputus, maka dilakukan perbaikan. Untuk kegiatan pemeliharaan arsip, dilakukan alih media ke dalam bentuk digital atau media lain berupa CD/ DVD.

Tahap akhir pengelolaan arsip statis yaitu akses dan layanan arsip. Akses arsip statis dimaknai sebagai ketersediaan arsip statis sebagai hasil dari kewenangan hukum dan otoritasi legal serta keberadaan sarana bantu untuk mempermudah penemuan dan pemanfaatan arsip (Arsip Nasional RI, 2009, 8). Lembaga kearsipan dikenakan kewajiban untuk menyediakan sarana dan prasarana dalam rangka mempermudah penemuan kembali dan pemanfaatan arsip statis bagi publik. Layanan akses arsip statis harus mempertimbangkan prinsip keutuhan, keamanan, dan keselamatan arsip serta sifat keterbukaan dan ketertutupan arsip sesuai dengan ketentuan perundangundangan.

\section{Layanan Arsip Statis Bagi Pengguna Difabel}

Arsip memiliki peranan penting dalam memperkuat memori manusia terhadap peristiwa atau kejadian di masa lalu, serta menjadi media dalam penyebaran pengetahuan. Arsip dapat membuka akses bagi akademisi maupun peneliti agar dapat mempelajari rekaman masa lalu untuk pengembangan dan kemajuan pengetahuan di masa depan. Hal ini semakin dimungkinkan juga dengan adanya kemajuan di bidang teknologi informasi yang menjadikan jarak dan waktu semakin pendek.

Dinas Kearsipan dan Perpustakaan Daerah X membuka layanan akses bagi pengguna dari berbagai kelompok, diantaranya yaitu masyarakat umum/perorangan, mahasiswa/pelajar, lembaga/instansi, dan peneliti asing. Pada periode Januari-Maret 2019, pengguna arsip di Dinas Kearsipan dan Perpustakaan Daerah X yang mengakses arsip statis terdiri atas dua kelompok, yaitu mahasiswa dan lembaga/instansi. Pengguna arsip dari kelompok mahasiswa/pelajar berjumlah 29 pengguna. Pengguna arsip yang berasal dari instansi berjumlah 6 pengguna. Berdasarkan fakta tersebut, sudah seharusnya Dinas Kearsipan dan Perpustakaan Daerah X, dan juga lembagalembaga kearsipan lain yang ada di Indonesia untuk lebih memperhatikan fasilitas 
layanan arsip yang mudah diakses bagi semua pengguna, khususnya bagi penyandang disabilitas. Di era keterbukaan informasi, kesadaran para penyandang disabilitas untuk mendapatkan pendidikan yang lebih tinggi semakin meningkat. Hal ini dapat dicermati dari minat mereka untuk mengikuti tes masuk perkuliahan dan juga keikutsertaan mereka dalam proses pendidikan di jenjang perguruan tinggi. Dalam konteks Dinas Kearsipan dan Perpustakaan Daerah X sendiri pernah dijumpai seorang mahasiswa penyandang disabilitas rungu yang mengakses referensi di ruang layanan pada tahun 2016.

Bentuk layanan arsip statis di Dinas Kearsipan dan Perpustakaan Daerah X dapat dilakukan secara manual maupun elektronik. Secara sederhana prosedur layanan arsip statis dalam bentuk manual di Dinas Kearsipan dan Perpustakaan Provinsi Daerah X adalah sebagai berikut:

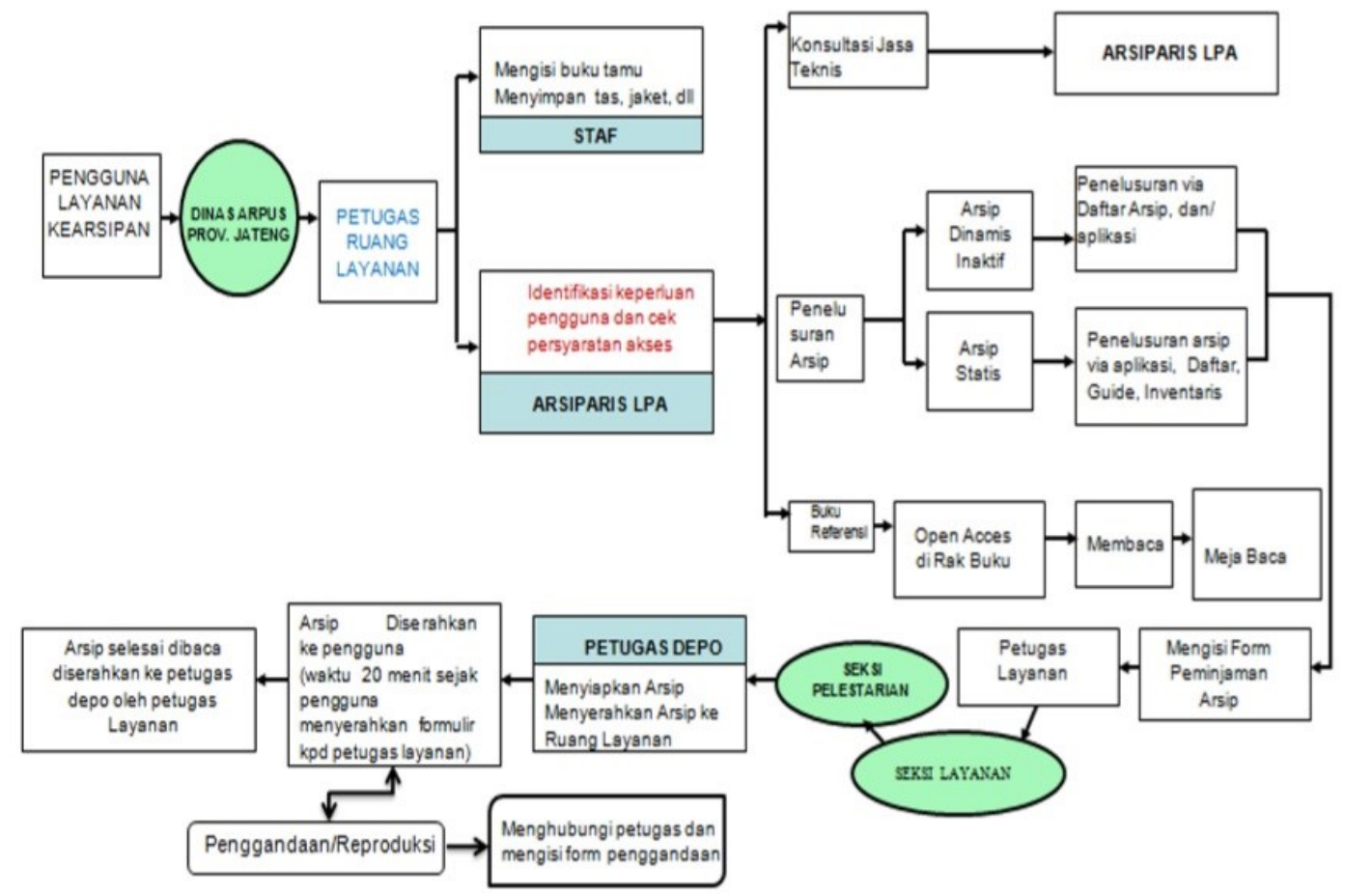

Gambar 2. Prosedur Layanan Arsip Statis

Di masyarakat Indonesia, masih dijumpai penyebutan istilah tunarungu dan tuli. Seringkali penyebutan istilah tunarungu dinilai lebih halus daripada istilah tuli. Namun faktanya, sebagian penyandang disabilitas rungu lebih memilih disebut dengan istilah tuli, dibanding istilah tunarungu. Menurut penyandang disabilitas tersebut, tunarungu adalah istilah medis untuk menggambarkan keterbatasan dari sebuah fungsi, sedangkan tuli merupakan istilah budaya atau cara berkomunikasi yang berbeda (Wawancara dengan narasumber A pada 27 Februari 2019).

Secara medis, tunarungu dibedakan menjadi dua kategori, yaitu tuli (deaf) dan kurang dengar (low of hearing). Tuli adalah seseorang yang indra pendengarannya mengalami kerusakan dalam taraf berat sehingga ia tidak berfungsi, sedangkan kurang dengar adalah seseorang yang indera pendengarannya mengalami kerusakan, tetapi masih dapat berfungsi untuk mendengar, baik dengan maupun tanpa menggunakan alat bantu dengar (hearing aids). 
Responden yang berstatus sebagai mahasiswa penyandang disabilitas rungu yang disimulasikan mengakses arsip tekstual pada praktik ini merupakan penyandang disabilitas rungu kategori tuli dan disabilitas wicara. Adapun prosedur layanan arsip bagi penyandang disabilitas di Dinas Kearsipan dan Perpustakaan Daerah X sebagai berikut:

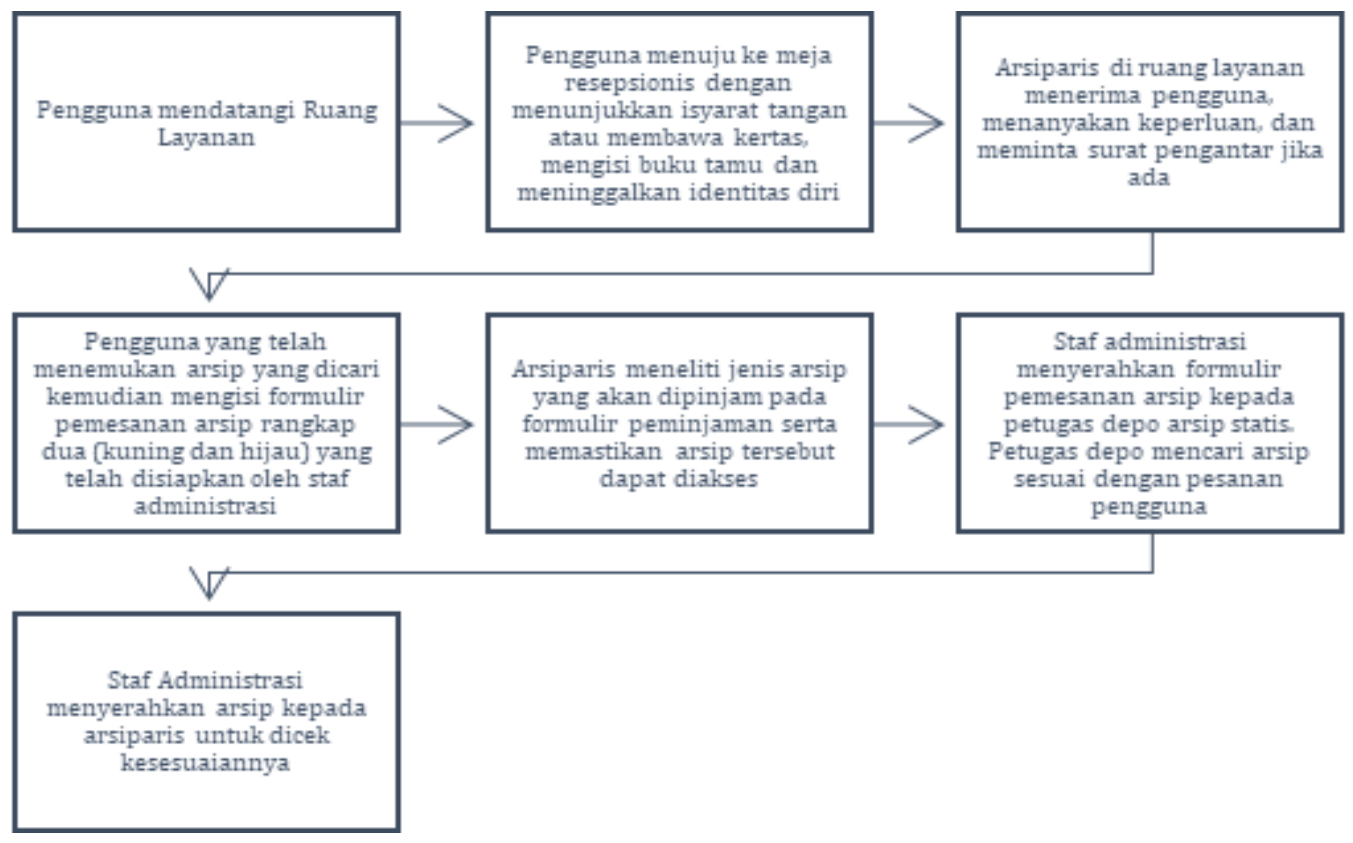

Gambar 3. Prosedur Layanan Arsip Statis

Bagi pengguna tunadaksa, kebutuhan atas aksesibilitas layanan arsip, lebih kepada pengkondisian lingkungan dan elemen bangunan yang mudah untuk dilalui oleh kruk maupun kursi roda. Sedangkan kebutuhan pengguna tunarungu adalah fasilitas yang mudah diakses dari aspek lingkungan dan elemen bangunan yang berkaitan dengan informasi visual. Hal ini disebabkan tunarungu hanya mengalami hambatan pendengaran dan komunikasi lisan. Adapun kebutuhan bagi pengguna tunanetra adalah fasilitas yang mudah dari aspek lingkungan serta elemen bangunan yang berkaitan dengan informasi berupa rabaan dan audio, karena tunanetra hanya mengalami hambatan dalam bentuk penglihatan.

\section{Sarana dan Prasarana Layanan Arsip}

Sarana prasarana yang tersedia di ruang layanan arsip di Dinas Kearsipan dan Perpustakaan Daerah X berfungsi untuk membantu dan mendukung pekerjaan dalam pelayanan arsip guna mewujudkan layanan publik yang optimal bagi pengguna. Untuk prasarana layanan arsip di Dinas Kearsipan dan Perpustakaan Daerah X terdiri dari ruang baca layanan, ruang transit arsip, dan ruang Daftar Khazanah Arsip. Masingmasing ruangan telah dilengkapi dengan sarana untuk memudahkan kegiatan layanan arsip.

Ruang baca layanan dilengkapi dengan informasi tertulis untuk mempermudah pengguna mengetahui tata tertib dan prosedur layanan arsip secara umum. Wujud informasi tertulis tersebut berupa poster yang berisi alur pelayanan arsip statis baik secara manual maupun elektronik, tarif penggandaan arsip berdasarkan Peraturan Gubernur Nomor 20 Tahun 2015 tentang Perubahan Kedua Atas Pergub No 24 Tahun 2014 tentang Perubahan Tarif Retribusi Daerah Provinsi X, tata tertib ruang layanan, dan Daftar Informasi yang Dikecualikan pada Dinas Kearsipan dan Perpustakaan Daerah X. Sarana yang berada di ruang baca, terdiri dari kartu pengguna arsip, loker, 
Daftar Khazanah Arsip, seperangkat komputer, meja penerimaan, meja layanan, meja baca, dan buku referensi.

Ruang baca layanan didesain untuk menciptakan kenyamanan bagi pengguna. Ruangan tersebut dilengkapi dengan pencahayaan dan pengaturan suhu yang cukup baik. Selain membaca arsip, selama jam kerja berlangsung, pengguna juga dapat membaca buku referensi dan laporan Praktik Kerja Lapangan yang diletakkan pada rak -rak buku.

Adapun sarana temu balik arsip statis sebagai sarana akses dan layanan arsip satis terdiri dari Daftar Pertelaan Arsip Permanen, Daftar Arsip Statis, dan Inventaris Arsip. Daftar Pertelaan Arsip Permanen merupakan sarana bantu penemuan kembali yang berisi daftar informasi arsip permanen pencipta arsip beserta jadwal retensi arsipnya. Daftar Arsip Statis adalah daftar yang berisi informasi terkait arsip statis pencipta arsip. Inventaris Arsip adalah sarana bantu penemuan kembali arsip statis yang memuat uraian informasi dari daftar arsip statis yang dilengkapi dengan pendahuluan dan lampiran.

Layanan umum yang diselenggarakan oleh Dinas Kearsipan dan Perpustakaan Daerah X dibagi dalam tiga kategori, yaitu layanan dengan lisan, layanan melalui tulisan, dan layanan dengan perbuatan. Pada saat awal memasuki gedung utama, pengguna difabel yang akan mengakses arsip di ruang layanan dilayani oleh resepsionis untuk mendapatkan kartu tamu dan mengarahkan pengguna ke ruang layanan. Pada lantai satu gedung utama, pengguna difabel juga akan akan menemukan layanan tertulis berupa informasi petunjuk terkait nama ruangan yang ada. Pada saat memasuki ruang baca layanan, pengguna difabel juga akan menemukan petunjuk berupa informasi tertulis terkait tata tertib dan prosedur layanan arsip, alur pelayanan arsip statis, tarif penggandaan arsip, tata tertib ruang layanan, dan Daftar Informasi yang Dikecualikan pada Dinas Kearsipan dan Perpustakaan Daerah X.

Berkaitan dengan kemudahan akses pada bangunan gedung yang ada di Indonesia, sudah dijelaskan dalam Peraturan Menteri Pekerjaan Umum dan Perumahan Rakyat Nomor 14 Tahun 2017 tentang Persyaratan Kemudahan Bangunan Gedung. Diantara hal yang tercakup di dalam kebijakan ini yaitu tentang prinsip Desain Universal dengan mempertimbangkan kebutuhan dan kemampuan Penyandang Disabilitas, anak-anak, lanjut usia, dan ibu hamil. Berkaitan dengan aksesibilitas arsip bagi pengguna difabel, dapat dicermati pada tabel berikut:

Tabel 1. Jenis Arsip dan Aksesibilitasnya Bagi Pengguna Difabel

\begin{tabular}{|l|l|}
\hline Arsip Foto & $\begin{array}{l}\text { Arsip yang dilayankan memiliki ukuran bervariasi, mulai dari ukuran } \\
\text { 2R hingga 4R. Pengguna dapat mengakses fisiknya secara langsung di } \\
\text { meja baca arsip. bukan dalam bentuk arsip yang sudah didigitalisasi di } \\
\text { komputer. Pengguna tunarungu, tunawicara, dan tunadaksa dapat } \\
\text { mengakses arsip foto tersebut secara langsung. Namun untuk pengguna } \\
\text { tunanetra, belum dapat mengakses arsip tersebut secara langsung, ha- } \\
\text { rus didampingi oleh petugas layanan. }\end{array}$ \\
\hline $\begin{array}{l}\text { Arsip } \\
\text { Kearsi- } \\
\text { tekturan }\end{array}$ & $\begin{array}{l}\text { Arsip memiliki ukuran yang bervariasi, mulai dari ukuran A0 hingga A3. } \\
\text { Sebagian arsip ini dilayankan fisiknya secara langsung di meja layanan, } \\
\text { dan sebagiannya lagi sudah dalam bentuk digitalisasi. Pengguna tunar- } \\
\text { ungu dan tunawicara dapat mengakses arsip tekstual tersebut secara } \\
\text { langsung. Namun untuk pengguna tunanetra dan tunadaksa, belum } \\
\text { dapat mengakses arsip tersebut secara langsung, harus didampingi oleh } \\
\text { petugas layanan. }\end{array}$ \\
\hline
\end{tabular}




\begin{tabular}{|l|l|}
\hline $\begin{array}{l}\text { Arsip } \\
\text { Rekaman }\end{array}$ & $\begin{array}{l}\text { Arsip rekaman suara yang dilayankan di ruang layanan, sudah dialihme- } \\
\text { dia ke bentuk CD/DVD. Pada umumnya rekaman suara ini memiliki for- } \\
\text { mat MP3 dan WAV. Arsip ini dilayankan oleh petugas dengan memutar } \\
\text { rekaman suara itu di komputer ruang layanan untuk didengarkan oleh } \\
\text { pengguna. Pengguna tunanetra dan tundaksa dapat mendengar suara } \\
\text { rekaman tersebut dengan baik. Namun untuk pengguna tunarungu, be- } \\
\text { lum dapat mengakses rekaman tersebut dengan baik karena rekaman- } \\
\text { rekaman suara tersebut belum tersedia transkrip berbentuk tekstual } \\
\text { sehingga ketika mengakses rekaman tersebut harus didampingi oleh } \\
\text { petugas layanan. }\end{array}$ \\
\hline $\begin{array}{l}\text { Arsip Film } \\
\text { dan Video }\end{array}$ & $\begin{array}{l}\text { Arsip film dan video tediri atas durasi yang berbedabeda, mulai dari 10 } \\
\text { menit hingga 2 jam. Arsip film dan video yang dilayankan di ruang } \\
\text { layanan, sudah dialihmedia ke bentuk CD/DVD. Pada umumnya mem- } \\
\text { iliki format MP4 dan MPEG dan belum memiliki transkrip dalam bentuk } \\
\text { tekstual. Arsip ini dilayankan oleh petugas dengan memutar film itu di } \\
\text { komputer ruang layanan untuk didengarkan oleh user. Pengguna tun- } \\
\text { daksa dapat melihat dan mendengar film tersebut secara utuh, namun } \\
\text { pengguna tunanetra hanya dapat mendengarkan suara saja tanpa } \\
\text { melihat filmnya. Untuk pengguna tunarungu hanya dapat melihat video } \\
\text { dan filmnya saja tanpa mendengar audio pada film tersebut belum, se- } \\
\text { hingga ketika mengakses rekaman tersebut harus didampingi oleh }\end{array}$ \\
\hline $\begin{array}{l}\text { Arsip Peta/ } \\
\text { kartografi }\end{array}$ & $\begin{array}{l}\text { Arsip kartografi memiliki ukuran yang bervariasi, mulai dari A0 hingga } \\
\text { A3. Sebagian arsip ini dilayankan fisiknya secara langsung di meja } \\
\text { layanan, dan sebagiannya lagi sudah dalam bentuk digitalisasi. } \\
\text { Pengguna tunarungu dan tunawicara dapat mengakses arsip tersebut } \\
\text { secara langsung. Namun untuk pengguna tunanetra dan tunadaksa, be- } \\
\text { lum dapat mengakses arsip tersebut secara langsung, harus didampingi } \\
\text { oleh petugas layanan. }\end{array}$ \\
\hline
\end{tabular}

Petugas yang melayani pengguna di ruang layanan pada setiap jam kerja terdiri dari satu arsiparis dan satu staf administrasi dari Bidang Layanan dan Pemanfaatan Arsip yang mendapat jadwal piket berjaga di ruang baca layanan. Total keseluruhan, terdapat enam arsiparis dan dua staf administrasi yang berjaga di ruang layanan arsip secara bergantian sesuai jadwal piket. Adapun tugas arsiparis di ruang layanan yaitu, memastikan pengguna sudah menyimpan tasnya di loker; meminta pengguna menunjukan surat pengantar atau surat permohonan jika ada, membantu dan mengarahkan pengguna dalam melakukan penelusuran arsip; meneliti kesesuaian arsip yang datang dari depot dengan permintaan pengguna; mengawasi pengguna saat memanfaatkan arsip di ruang baca layanan; mengarahkan pengguna saat memilih dan memilah arsip yang akan digandakan; menunjukan harga jasa reproduksi arsip; meneliti keutuhan arsip setelah dicopy; memberi tanda arsip-arsip yang sudah selesai dipakai dan siap dikembalikan ke depo dan meminta staf untuk mengembalikan ke depo; menyimpan arsip yang masih dipergunakan di ruang transit; dan mengarahkan pengguna untuk mengisi indeks kepuasan masyarakat pada komputer tamu di depan pintu masuk utama.

Arsiparis yang ada terdiri atas arsiparis utama, arsiparis madya, arsiparis ahli muda, dan arsiparis mahir. Berdasarkan data ini dapat diketahui bahwa petugas layanan yang ada di Dinas Kearsipan dan Perpustakaan Daerah X merupakan profil sumber daya manusia yang seharusnya sudah menguasai khazanah arsip yang dilayankan di ruang layanan. Untuk pengguna disabilitas, arsiparis akan membantu pengguna mengakses arsip sesuai dengan kebutuhannya. 


\section{Evaluasi Aksesibilitas Layanan Arsip Statis}

Ada beberapa faktor yang mempengaruhi keberhasilan kegiatan layanan arsip statis bagi pengguna difabel, yaitu faktor kebijakan, faktor fasilitas, dan faktor petugas layanan. Pertama dari aspek kebijakan, Dinas Kearsipan dan Perpustakaan Daerah X telah memiliki Standar Operasional Prosedur (SOP) Pelayanan Peminjaman Arsip Statis Tahun 2016. Acuan yang menjadi dasar pertimbangan pembuatan SOP pelayanan peminjaman arsip ini yaitu UndangUndang Nomor 43 Tahun 2009 tentang Kearsipan, Undang-Undang Nomor 14 Tahun 2014 Tentang Keterbukaan Informasi Publik, Peraturan Pemerintah Nomor 28 Tahun 2012 Tentang Pelaksanaan Undang-Undang Nomor 43 Tahun 2009 tentang Kearsipan, Peraturan Daerah Nomor 1 Tahun 2015 Tentang Penyelenggaraan Kearsipan di Provinsi X, Peraturan Gubernur Nomor 20 Tahun 2015 tentang Perubahan Kedua Atas Peraturan Gubernur Nomor 24 Tahun 2014 Tentang Perubahan Tarif Retribusi Daerah Provinsi X, dan Peraturan Kepala ANRI Nomor 28 Tahun 2011 Tentang Pedoman Akses dan Layanan Arsip Statis.

Berdasarkan dasar-dasar aturan yang digunakan pada pembuatan SOP, dapat terlihat bahwa belum ada acuan kebijakan yang secara khusus mengatur tentang pengguna difabel. Hal ini menjadi salah satu faktor yang perlu dikaji kembali, sebab SOP tersebut merupakan landasan kerja petugas dalam melakukan kegiatan pelayanan di ruang layanan arsip. Dengan adanya SOP layanan arsip yang secara jelas menggambarkan mekanisme layanan akses arsip bagi pengguna difabel, maka akan mempermudah petugas layanan dalam memenuhi hak-hak pengguna difabel yang akan mengakses arsip statis.

Kedua, yaitu aspek fasilitas. Kategori pengguna tunanetra, belum tersedia buku-buku dengan huruf braille yang mampu menjadi bahan penunjang ketika mengakses arsip, dan juga komputer pembaca layar dengan program Job Access With Speech (JAWS) utnuk mempermudah pengguna tunanetra melakukan penelusuran arsip secara elektronik. Sedangkan kategori pengguna tunarungu belum tersedia fasillitas penerjemah bahasa isyarat (interpreter sign language), dan aplikasi pentransfer suara menjadi tulisan saat memutar arsip rekaman suara dan video di komputer. Adapun kategori pengguna tunadaksa, belum tersedia fasilitas toilet khusus yang accessible bagi penyandang tunadaksa.

Ketiga, yatu aspek petugas layanan. Kesadaran pimpinan serta petugas yang berkecimpung dalam tugas pelayanan arsip statis mempengaruhi keberhasilan lembaga kearsipan dalam pemenuhan hak-hak pengguna difabel dalam mengakses arsip. Sampai dengan penelitian ini dilakukan, belum ada pelatihan khusus bagi petugas layanan untuk melatih petugas ketika berhadapan langsung dengan pengguna difabel, karena memang jarang sekali pengguna difabel yang mengakses arsip di Dinas Kearsipan dan Perpustakaan Daerah X. Hal ini juga sebabkan oleh kurangnya informasi yang diterima pengguna difabel terkait layanan arsip yang ada di Dinas Kearsipan dan Perpustakaan Daerah X.

Upaya yang pernah dilaksanakan oleh Dinas Kearsipan dan Perpustakaan Daerah X dalam memenuhi aksesibilitas layanan arsip yang mudah bagi semua pengguna diantaranya yaitu, pemenuhan kebutuhan akses masuk gedung yang accessible, serta adanya petugas yang memang diarahkan untuk memenuhi kebutuhan pengguna. Upaya yang saat ini sedang dilaksanakan yaitu proses alih media arsiparsip tekstual, arsip non tekstual, dan juga penginputan daftar arsip statis ke Sistem Informasi Kearsipan Nasional (SIKS) agar dapat mempermudah pengguna dalam mencari arsip.

\section{KESIMPULAN}

Dinas Kearsipan dan Perpustakaan Daerah X merupakan salah satu lembaga kearsipan daerah yang mempunyai tugas pokok membantu kepala daerah melaksanakan penyusunan dan pelaksanaan kebijakan pemerintahan bidang kearsipan dan perpustakaan. Dinas tersebut dibentuk berdasarkan Peraturan Daerah Provinsi X nomor 9 tahun 2016 tentang pembentukan susunan perangkat Daerah Provinsi X. Koleksi arsip statis yang dimiliki dinas bermanfaat bagi publik, terutama bagi akademisi dan para peneliti. Hal ini diwujudkan Dinas Kearsipan dan Perpustakaan Daerah X melalui upaya pelayanan arsip statis yang tersedia di ruang layanan 
arsip. Penelusuran arsip statis di ruang layanan arsip ini dapat dilakukan secara manual maupun elektronik.

Sudah selayaknya lembaga-lembaga kearsipan yang ada di Indonesia memperhatikan fasilitas-fasilitas layanan arsip yang mudah diakses bagi semua pengguna, termasuk juga bagi penyandang disabilitas. Pada tahun 2016 sudah pernah ada seorang mahasiswa penyandang tunarungu sekaligus tunawicara, yang mengakses referensi di ruang layanan Dinas Kearsipan dan Perpustakaan Daerah X, yaitu mahasiswa program studi ilmu perpustakaan Universitas X. Prosedur layanan arsip statis secara manual bagi pengguna tunarungu terdiri atas beberapa tahapan. Pertama, pengguna mendatangi ruang layanan yang terletak di lantai satu Gedung Utama Dinas Kearsipan dan Perpustakaan Daerah X, lalu menuju ke meja resepsionis dengan menunjukkan isyarat tangan atau membawa kertas untuk berkomunikasi. Pengguna akan diarahkan oleh resepsionis untuk mengisi buku tamu online dan meletakkan barang di loker sebelum masuk ke ruang layanan.

Di ruang layanan, arsiparis yang sedang bertugas piket membantu pengguna dalam mengakses arsip yang dibutuhkan melalui daftar khazanah arsip dan sarana bantu temu balik arsip. Pengguna yang telah menemukan arsip yang dicari kemudian mengisi formulir pemesanan arsip rangkap dua (kuning dan hijau) yang telah disiapkan oleh staf administrasi. Staf administrasi akan memproses peminjaman arsip tersebut dan pengguna dapat menunggu. Setelah arsip dicarikan, arsiparis akan menyerahkan arsip tersebut pada pengguna dan mendampingi pengguna dalam mengakses arsip. Pengguna dapat membaca dan menggunakan arsip di ruang baca layanan atau meminta staf administrasi untuk menggandakannya dengan mengisi formulir penggandaan terlebih dahulu.

Upaya yang pernah dilaksanakan oleh Dinas Kearsipan dan Perpustakaan Daerah X dalam memenuhi aksesibilitas layanan arsip yang accessible bagi semua pengguna diantaranya yaitu, pemenuhan kebutuhan akses masuk gedung yang accessible, serta adanya petugas yang memang diarahkan untuk memenuhi kebutuhan pengguna. Upaya yang saat ini sedang dilaksanakan yaitu penambahan tenaga kontrak untuk proses alih media arsip-arsip tekstual, arsip non tekstual, dan juga penginputan daftar arsip statis ke Sistem Informasi Kearsipan Nasional (SIKS) agar dapat memaksimalkan fitur pada aplikasi dan mempermudah pengguna dalam penelusuran arsip statis.

Ada beberapa faktor yang menjadi kendala dalam kegiatan layanan arsip statis bagi pengguna difabel di Dinas Kearsipan dan Perpustakaan Daerah X, yaitu faktor kebijakan, faktor fasilitas, dan faktor petugas layanan.

\section{DAFTAR PUSTAKA}

Amsyah, Zulkifli. (1989). Manajemen Kearsipan. Jakarta : PT Gramedia Pustaka Utama

Badan Arsip Daerah Provinsi X, (2005). Merajut Kearsipan Provinsi X. Semarang : Badan Arsip Daerah Provinsi X

Bettington, Jackie. (ed). (2008). Keeping Archives. Canberra: Australian Society of Archivist

Martono, Boedi. (1994). Penyusutan dan Pengamanan Arsip Vital dalam Manajemen Kearsipan. Jakarta : Pustaka Sinar Harapan

Moenir, H.A.S. (2001). Manajemen Pelayanan Umum di Indonesia. Jakarta : Bumi Aksara

Ricks, Betty R. et al., (1992). Information and Image Management: A Records System Approach. Cincinnati : South Western Publishing CO

Schellenberg, T.R. (2003). Modern Archives: Principles and Techniques. Chicago : The Society of American Archivists

Soleh, Akhmad. (2016). Aksesibilitas Penyandang Disabilitas Terhadap Perguruan Tinggi : Studi Kasus Empat Perguruan Tinggi Negeri Yogyakarta. Yogyakarta : LKIS Pelangi Aksara 
Wirladihardjo, Moeftie. (1987). Beberapa Masalah Kearsipan di Indonesia. Jakarta : Balai Pustaka

Rasiono, Galih. (2013). Layanan Bagi Pemustaka Berkebutuhan Khusus di Perpustakaan Nasional Republik Indonesia. Depok: Universitas Indonesia

Saurombe, N.P. dan Patrick Ngulube, 2016. Public Programming Skills Of Archivists In Selected National Memory Institutions Of East And Southern Africa. Mousaion. Volume 34. No. 1

Taufik, M. 2017. Arsip Prosiding : Pemanfaatan Arsip yang Bernilai Nasional sebagai Rekam Informasi Ilmiah . Jakarta : Prosiding Lokakarya Nasional Dokumentasi dan Informasi

Peraturan Gubernur X Nomor 36 Tahun 2018 tentang Perubahan Atas Peraturan Gubernur X Nomor 74 Tahun 2016 tentang Organisasi dan Tata Kerja Dinas Kearsipan dan Perpustakaan Provinsi X

Peraturan Daerah Provinsi X Nomor 1 Tahun 2015 tentang Penyelenggaraan Kearsipan di Provinsi X

Peraturan Menteri Pekerjaan Umum dan Perumahan Rakyat Nomor 14/PRT/M/2017 tentang Persyaratan Kemudahan Bangunan Gedung

Undang-Undang Republik Indonesia nomor 43 tahun 2009 tentang Kearsipan

Undang-Undang Republik Indonesia Nomor 25 Tahun 2009 Tentang Pelayanan Publik

Undang-Undang Republik Indonesia nomor 39 tahun 1999 Tentang Hak Asasi Manusia

Undang-Undang Nomor 19 Tahun 2011 Tentang “The Convention on the Human Rights of Persons with Disabilitie"(Hak-hak Penyandang Disabilitas) 